medical and science students in Aberdeen and Glasgow, and also to postgraduates who have attended the recent courses in basic virology at Glasgow.

\section{Director of the Forest Products Research Laboratory: Mr. J. Bryan}

Mr. J. BRYAN, director of the Forest Products Research Laboratory of the Ministry of Technology, retired from the public service on December 31, 1965. With the exception of a short period with Dorman Long, Ltd., early in his career, he devoted the whole of his working life to the study of timber and the service of the Forest Products Research Laboratory, which he joined virtually at its inception in 1926. He formed and led the section working on wood preservation and later became head of the Timber Mechanics Section. He took charge of all engineering investigation in the Laboratory in 1945 and was appointed assistant director in 1954 and director in 1962. An engineer by training and inclination, with a keen interest in natural products and processes, he was well fitted to assist in the transformation of timber from a craft to an engineering material and the establishment of a scientific basis for wood technology. During his period of service with the Laboratory he saw great advances on both these fronts and he saw the Laboratory develop into a leading world authority on timber and its use. His career spanned most of the lifo to date of the Forestry Commission, with which he worked in close co-operation, especially when its plantations began to reach the age when timber properties could be tested. He was for some years chairman of the joint Committee on Research into Home-Grown Timbers of the Department of Scientific and Industrial Research and the Forestry Commission.

Mr. T. A. Oxley

Mr. T. A. OXLEY has been appointed director of the Ministry's Forest Products Research Laboratory, Princes Risborough, in succession to Mr. Bryan. The appointment took effect from March 1. Mr. Oxley was born in Hampstead, where he attended the Haberdashers Aske's School, and graduated with honours from the Imperial College of Science and Technology in 1933. After spending 2 years on postgraduate research, he worked for 3 years as a demonstrator at Imperial College. He then joined a group in the Department of Zoology at Imperial College, investigating, as a grain-specialist, pest infestation of stored products. This group later formed the Pest Infestation Laboratory of the former Department of Scientific and Industrial Research, where Mr. Oxley became head of the biology section and later of the grainstorage section. He was appointed assistant director of the Tropical Products Institute in 1959. For the past 5 years Mr. Oxley has been a deputy commissioner, scientific and engineering directorate, of the Civil Service Com. mission.

\section{Council for National Academic Awards: Recognized Degree Courses}

THe first roport of the Council for National Academic Awards covers the year ended September 30, 1965, and records the establishment of three Boards of Studies for Arts and Social Studies, Science and Technology, and Research Dogrees, as well as of eighteen Subject Boards (Pp. 33. Recognised Degree Courses. List No. 2. Pp. 6. London: Council for National Academic Awards, 1965). The Council considered 67 courses in business studies, science and technology proposed by Colleges to lead to the Council's degrees; arrangements havo been made to award the Council's degrees to holders of either the Diploma in Technology or Membership of the College of Technologists who wish to convert their awards. At the beginning of the 1965-66 academic year, 4,073 students were enrolled in 89 courses leading to the Council's degrees, including 129 first-year students in five courses leading to a B.A. degree in business studies. Of fiftyseven courses in science and technology considered by the Council, seventeen were approved to start in 1965 and a further seven to start in 1965 or 1966 subject to satisfaction on outstanding points; thirty-three were rejected. Five out of ten courses in business studies were approved to start in 1965 ; two were approved to start in $1966 \mathrm{sub}-$ ject to satisfaction on several points; three were rejected. Of the 4,073 students enrolled, 1,052 were in mechanical and production engineering, 978 in electrical and eloctronic engineering, 463 in eivil engineering, 410 in chemistry, chemical technology and industrial chemistry, 359 in physics and physical electronics, and 220 in aeronautical engineering. Appendixes give the membership of the various Boards of Studies.

\section{Sixth-form Teaching}

'THE Schools Council is in the unenviable position of having to foster change in the British educational system without treading on the corns of its sponsors-principally the local authorities responsible for education systems, organizations of professional teachers and the Department of Education and Science. In the circumstances it is inevitable that it should spend a good deal of its energy flying kites, talking of innovation and then waiting to see whether the result is delight or revolution. This seems to have been the spirit in which the Schools Council organized a conference in Nottingham a year ago to parade before a small group of teachers some recent suggestions as to how the pattern of science teaching in the sixth forms of British secondary schools may, in the near future, change. A record of this conference has now been published (Science in the Sixth Form, H.M.S.O., 4s. 6d.).

Outside the United Kingdom it may seem strange that British schools should regard as daring an experiment in which some of the material now taught to senior secondary pupils under the separate labels of physics and chemistry should be combined in a single course called physical science. Indeed, the proposal is only meaningful in the context of the British sixth form, where most students aiming at university or higher education follow courses in three specialized subjects, and where schools are urged, sometimes vainly, to devote a third of the time available to broader pursuits (including physical education). The most compelling argument for physical science, advanced at Nottingham, is that such a course would make it possible for those going on to science departments at universities to know something of the biological and the physical sciences, and to learn some mathematics as well. At present it is all too common that students intending to go on to university are required to choose, at sixteen or so, on the particular discipline in which they intend to graduate 5 years later, and that they should promptly direct their studies to that end. A course in physical science would make it possible to postpone this choice for 2 years and-giddy thought-might even allow some intending scientists to read a little history.

Prospects for Change

A group of a dozen schools is likely to try out such a course in the years immediately ahead. The value of the experiment will obviously depend on whether British universities are willing to give it a fair wind. Nothing said at the Nottingham conference can be used to predict how things will go, but when the results of the first experiment are available for study, the universities are bound to worry a great deal, in part legitimately, before deciding what their attitude will be. It would be a great, though uncovenanted, benefit if one consequence were the fuller involvement of British universities in the creative evolution of the school curriculum.

A more radical proposal given an airing at the Nottingham conference was for a pattern of sixth-form study 